\section{PD-017＼cjkstart幼児期における遊びの自発性とレジ リエンスとの関連}

○橋本 久美 ${ }^{1}$, 中野 茂

('札幌国際大学)

キーワード：遊び，レジリエンス，唾液中コルチゾール

【目的】幼児期からの遊び経験はストレス緩和効果を導き, 遊戯的性格 が強い学生は, ストレス耐性が高いことが報告されている。遊びの楽し さは，ポジティブ情動を喚起し，レジリエンスを釀成する。本研究では, 幼児の遊びによる情動コントロールが可能であることを実証する。【方法】 $\mathrm{S}$ 市の $\mathrm{A}$ 幼稚園の年中組17名に登退園の 2 回に分けて唾液採取を行い, 実駼協力者の母親に, Children's Playfulness Scale (CPS; Barnett, 1991) 邦訳版を施行した。質問紙と唾液検体が揃った15名の親子のデー夕を分 析した。【結果】CPS の認知的自発性は, 各々登園前唾液中コルチゾール 濃度との間に $\mathrm{r}=-.65(\mathrm{p}<.01)$, 退園前唾液中コルチゾール濃度との間 に $\mathrm{r}=-.73(\mathrm{p}<.01)$ の相関が認められた。コルチゾールは, CPS との相 関は認められなかった。CPS の自発的身体活動は，唾液中コルチゾール の一日変化量との間に $\mathrm{r}=-.58 （ \mathrm{p}<.05 ）$ の相関が認められた。【結論】 唾液中コルチゾールは日内変動があり午後には増加する傾向にあるが，園 での自由な遊びはコルチゾールの減少に寄与すると考えられる。まず自 発的な身体運動がコルチゾールの生成を抑制し，楽しさ感情が遊びを持 続させると推測された。

連絡先 E-mail : h-hashimoto@ts.siu.ac.jp

\section{PD-018＼cjkstart鉄道飛び込み自殺の多発する駅及び 飛び込み地点の特徵}

○末 新 ${ }^{1}$

('和光大学)

キーワード：鉄道自殺，自殺予防

鉄道自殺は多大なる経済的損失を発生させるが，その対策は十分に進 んでいない。そこで本研究では, 鉄道自殺が発生しやすい駅及びホーム における飛び込み地点の特徴を明らかにした。研究 1 では, 2014年 4 月〜 2019年 9 月に扔ける国内の大手鉄道会社全線における駅ごとの飛び込み 自殺発生件数をまとめ, 駅の特徴を独立変数, 自殺発生件数を従属変数 としたポアソン回帰分析を行った。研究 2 では, 鉄道飛び込み自殺が多 発する駅のホーム上を鉄道会社職員と訪れ, 飛び込み発生地点 $(n=50)$ の特徵を明らかにし, 各地点での自殺発生割合を数量化した。研究 1 の 結果, 自殺多発駅は, 通過列車が通る, 利用客数が多い, 近隣に精神科 病院があるという特徴を有することが示唆された。研究 2 の結果, 飛び 込み地点には 4 つの特徴（ベンチ・待合室前，ホーム始端，ホーム侵入 口，運転手からの物陰）があり, 飛び込み地点の約半数はベンチ・待合 室の前であった。駅およびホーム上の自殺の発生場所には特定の偏りが あるため,こうした地点に対して集中的に自殺対策を実施すること（例： ホーム上のパトロール）が効果的な自殺対策の実現につながると考えら れる。

連絡先 E-mail：h_sueki@wako.ac.jp

\section{PD-019＼cjkstart体験の観察と well-being の関連一縦 断調査による注意の制御の効果一}

\author{
○高田 圭二 $^{1}$, 杉浦 義典 $^{2}$

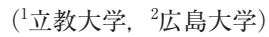 \\ キーワード：体験の観察，ウェルビーイング，注意の制御
}

\section{PD-020 倫理的な言葉遣い尺度の開発および 信頼性と妥当性の検討}

○砂田 安秀 ${ }^{1}$, 杉浦 義典 ${ }^{2}$

(1岩手大学, ${ }^{2}$ 広島大学)

キーワード：マインドフルネス，倫理的な言葉遣い

近年，マインドフルネストレーニングに「(1)他者を害さず，(2)思いや る」という倫理に関する介入要素を加えることで，より効果的な介入プ ログラムが開発される可能性が示されている（砂田ら，2019）。一方で, 具体的にどのような倫理の介入要素を導入することが有効であるか議論 はなされていない。日本人に受け入れられやすいと予想される介入の一 つとして,「嘘や悪口を言わない」「気遣う言葉をかける」といった「倫 理的な言葉遣い」の促進があげられる。そこで, 本研究では介入技法の 開発のために,「倫理的な言葉遣い」の測定尺度の開発を試み, 信頼性と 妥当性の検証を行った。まず，文献のレビューによって「(1)他者を害す る抑制する（８項目）」「(2)他者を思いやる言葉を使う（9 項目）」といっ た $2 つ の 尺$ 度の項目が選定され，心理学の専門家によって内的妥当性の 検討が行われた。大学生457名が質問紙に回答し, 探索的因子分析によっ て2つの尺度についてそれぞれ項目の選定が行われた。最終項目は十分 な内的整合性が確認され，信頼性が確認された。また，相関分析によっ て，関連すると予想された尺度との正の相関がみられたことから，2つ の尺度の妥当性が示された。

連絡先 E-mail：syorinesi4@yahoo.co.jp 